\title{
No caminho certo!
}

ompletamos os primeiros dez meses à frente da SBR, com muitas dificuldades, sanadas com um sem-número de reuniões administrativas e conversas com outros colegas e ex-presidentes. Apesar disso, acredito estarmos no caminho certo.

Não nos afastamos do plano geral de ações propostas para o ano de 2003, mas descobrimos que vários objetivos, na pauta de 2004, não puderam esperar e tiveram de ser resolvidos imediatamente para aprimorar o funcionamento de nossa Sociedade. Uma das maiores dificuldades de se enfrentar simultaneamente vários problemas é de ordem financeira: todos os serviços necessários para modernizar a SBR apresentam alto custo, e tudo que se imagina fazer representa uma pequena fortuna. Estamos desenvolvendo um cronograma de trabalho dentro dos limites suportáveis pela SBR.

Deixando as lamúrias de lado e sendo mais objetivo, comunico-lhes que as Jornadas programadas para 2003 (assim como o Encontro de Residentes e Docentes) estão todas encaminhadas e, graças à competência de seus maestros, dando muito pouco trabalho à Diretoria Executiva e ao Diretor Científico. Os programas apresentados, os esquemas de comercialização dos eventos, tudo que nos chega, está dentro do que esperávamos para tais eventos. Temos batalhado muito para que os eventos sejam realmente regionais e tenham pequenas modificações no esquema das reuniões científicas (o que não tem sido fácil!). Temos procurado, também, na medida do possível, dar vez aos colegas mais jovens que vêm se destacando em diversas áreas, indicados pelos Chefes dos Serviços de Reumatologia de todo o Brasil.

Já disponibilizamos no site o projeto de reforma do Estatuto e do Regimento Interno, elaborados sob nossa orientação pela Assessoria Jurídica, contratada de forma independente. Um trabalho difícil e custoso, por causa da antigüidade de nossos documentos, dos acréscimos sucessivos de itens mais novos que contradizem outros mais antigos, da confusão sobre o que é Estatuto e sobre o que é Regimento Interno, e das exigências de adaptação imediata ao novo Código Civil brasileiro, em vigor desde o início deste ano. Felizmente, estamos concluindo o trabalho, que o usuário encontra, como dissemos, no site. Esperamos suas opiniões para melhorá-lo, antes de sua apresentação para votação, na Assembléia Geral Extraordinária em setembro de 2003.

A Assessoria de Informática da SBR e a ETCetera Editora, de São Paulo, fazem um bonito e também custoso trabalho, ainda não concluído, de recuperação de nosso cadastro e reformulação de nosso site, que deverão auxiliar o serviço das Comissões, do Pronuclear, bem como, num futuro próximo, em nossa atualização científica. Se toda as providências que estamos tomando derem certo, acreditem, teremos, até dezembro de 2003, um site dinâmico, do qual deveremos nos orgulhar. Aguardem!

Estamos enfrentando muitas dificuldades em atuar em todos os Estados, na exigência do cumprimento da Portaria que dispõe sobre a dispensação de medicamentos gratuitos pelo Sistemas de Saúde para os portadores de artrite reumatóide. Insistimos que a luta não deve ser só dos presidentes das regionais da SBR, mas sim de todos nós reumatologistas, prescrevendo os medicamentos e orientando corretamente os pacientes para que façam valer os seus direitos, garantidos pela Constituição brasileira.

Acredito que o leitor deste editorial já esteja ansioso para que o texto termine, para que possa, naturalmente, apreciar a bela seleção de temas científicos selecionados pela dra. Iêda Laurindo e seu Conselho Editorial. Assim, despeço-me agradecendo a todos que estão nos ajudando a tornar a SBR cada vez maior e mais devotada à sua única finalidade: servir bem a todos os seus associados.

\section{Caio Moreira}

Presidente DA SBR 